821.163.41.09-2 Симовић Љ.

821.163.41.09-13:398

https://doi.org/10.18485/msc_pred.2021.9_10.ch10

Бошко СУВАЈџИЋ

Универзитета у Београду

Филолошки факултет

\title{
БОЈ НА КОСОВУ ЉУБОМИРА СИМОВИЋА И КОСОВСКА ЛЕГЕНДА
}

„Душе Симовићеве драмске поезије нису запитане над судбином света; оне су пре свега зачуђене чињеницом сопственог постојања...”

(Егон Савин)

\section{Драмски опус Љубомира Симовића}

Драмски опус Љубомира Симовића сачињен је од четири драме које су написане у периоду од 1973. до 1989. године. То су Хасанагинииа, Чудо у „Шаргану”, Путујуће позориште Шопаловић и Бој на Косову. Драму Бој на Косову Љубомир Симовић је написао 1988. године на позив Југословенског драмског позоришта уочи прославе шестстогодишњице Косовске битке. За драму се заинтересовала и Телевизија Београд, која је најпре желела да по тој драми сними серију. Драма никада није изведена на сцени. Текст драме песник је прерадио крајем 2002. године, незадовољан њеним уметничким дометима и драматуршким решењима. (У ствари, писац није био задовољан степеном аутономности дела у односу на косовску легенду.)

Заснована на историјском догађају, Бој на Косову је драма која се обликује из нуклеуса мита. У подтексту приче је косовска легенда која обједињује стару средњовековну књижевност, косовску епику, историографију, мит. Веродостојност драмског дела, међутим, исправно је процењивао аутор, мора да почива на премисама сопствене, позоришне уметности. 
Способности за театарску игру. Драма мора бити истинита и уверљива из сопственог драматуршког језгра и са самосвојним уметничким решењима (Станисављевић 2006: 48).

Драме Љубомира Симовића карактеристичне су по отклону од система традиционалне културе који их сврстава у врхове српске драме двадесетог века. Симовић 1989. године, у којој је обележена шестстогодишњица Косовске битке, објављује драму Бој на Косову (Београд: СКЗ - Београдски издавачко-графички завод), која у себи нема отклона од традиције. Овај драмски текст узет је за сценарио за истоимени филм Здравка Шотре, који је пригодно снимљен исте године. Друга верзија драме објављена је четрнаест година касније, у нешто другачијим политичким и друштвеним околностима: Бој на Косову: Друга верзија (Београд, Стубови културе, 2003). Симовићево придржавање основног, у великој мери, „окамењеног” обрасца приказивања косовског мита, део је актуелног културолошког и политичког схватања идентитета у српском народу. Сви писци у српској књижевности који су имали намеру да литерарно осветле косовски мит наилазили су на један исти проблем нелитерарне природе (Громовић 2020: 573-574).

Није ретка појава да писци 20. века, попут Симовића, инспирацију проналазе у народној епској традицији. Косовска легенда је, међутим, спутана оквирима не само епске поезије већ и националне идеологије. У њој је, попут античких трагедија, све унапред познато, одређено, задато, али истовремено крајње драматично. Сви ликови су умрежени вишеструким спонама: историјским, сижејним, породичним, личним. Сви имају своје, вековима брушене, делокруге и ,задужења”. Своје прецизне и тачно одмерене улоге. Сви тежишни односи, мотиви, начин грађења ликова и мотивација њихових поступака канонизовани су у традицији, устоличени у колективној свести, сакрализовани у духу нације. Косовска легенда, тако, дубински живи у тексту, а превентивно и у свести аутора, и пре него што почне да ради на њему. Као „врхунски израз националне идеологије, религије и етике”, она на много начина „обавезује” писца. Или, како то мудро закључује Марта Фрајнд: „Докле год Косово буде у свести нашег народа представљало историјски и политички проблем - косовска легенда и њена књижевна тумачења биће ограничена" (Фрајнд 1996: 179-190).

\section{Косовска епика и драма}

Ослањање писаца српске историјске драме на народну епску поезију није Симовићев изум. Али га је он несумњиво подигао на виши ниво, пре свега у отклону према традицији, како би она могла бити приказана као систем универзалних модела, делатних и у савременом свету: 
Народна епика имала је огроман утицај на српску историјску драму. Врло често је одређивала њену тематику, заплет и приказ главних јунака. У драмском опусу Љубомира Симовића важно место, и по квалитету и по бројности, заузимају драме по мотивима из народне традиције - Хасанагиниияа и Бој на Косову. Основни принцип који учествује у грађењу обе драме је принцип осавремењавања. Народна епика о боју на Косову је у том смислу представљала одличну полазну грађу, пошто је и сама подложна принципима универзалности, који су трагику пораза на бојном пољу уздигли до националне легенде (Катински 2012: 83-84).

Исходиште драме су косовска легенда и три основна мотива на којима она почива: „косовско опредељење” кнеза Лазара и његова мученичка смрт; подвиг оклеветаног јунака Милоша Обилића; издајство Вука Бранковића. У првој верзији Симовићевог Боја на Косову развијени су и остали препознатљиви мотиви: ухођење Турака, извештај о бројности турске војске, причешћивање војске пре боја, кнежева вечера (каталог званица, здравица, клетва и заклетва), одлазак у турски табор, Милошев подвиг и смрт. Лазарево заробљавање, начин сахрањивања кнеза Лазара, обретеније главе, чуда после смрти. Тужбалица Косовке Девојке и збивања после боја:

Окосницу косовске легенде чине мотиви мученичке смрти кнеза Лазара, подвиг Милоша Обилића и издајство Вука Бранковића. Историјска стварност настојала се у поезији уклопити у већ постојеће тематске целине. У познате и распрострањене мотиве имплементирале су се историјске чињенице (битке, мегдани, каталог ратника, вечера, добијање писма, оклеветан јунак, злокобни снови, ухођење, издајник) (Ђорђевић 1990: 14). Избори кнеза Лазара, Милоша Обилића и Вука Бранковића повољно су тло за настајање драмских дела са косовском тематиком, јер проблематизују питање трагичке кривице јунака и представљају изврсну подлогу за драмски конфликт (Катински 2012: 84).

У драми су присутне препознатљиве хиперболе из епске песме о величини и бројности турске војске:

\section{МИЛИЦА}

Прича се да је турска војска тако велика да се чује два сата пре него што се види!

(Симовић 2003: 12)

Као ни косовска епика, у којој је све драмски спрегнуто, концентрисано, усмерено на духовну суштину, ни Симовићева драма не трпи понављања (то је и основни разлог писања друге верзије). Тако се Муратово писмо-ултиматум, као покретач драмске радње, спомиње тек у разговору persona dramatis, патријарха Спиридона и кнеза Лазара. Сам садржај писма, међутим, концентрисани је дестилат епског предлошка (Вук СНП II: 50/1), чиме се постиже ефекат „препознавања и поистовећивања”: 
Да смо сложни,

Мурату тешко да би на памет пало

да тражи да му се, како овде пише, покоримо, да тражи да му признамо његову врховну власт, да тражи да му предамо кључеве од градова, да дајемо војску, да плаћамо харач!

(Симовић 2003: 11-12)

У Симовићевој драми, мотив ухођења се везује за Косанчића Ивана и Топлицу Милана, што је, ако изузмемо одсуство Милоша Обилића, у складу са усменим изворима.

Кнез Лазар је у епској традицији славни, честити кнез, српска круна златна, од Србије глава итд. И у Симовићевој драми он је представљен као недостижни етички узор којег красе све врлине. У другој варијанти Зидаља Раванице непознатог сељака из Рудничке нахије истакнуте су и кнежеве негативне особине, као што су гордост, частољубље, лаковерност и сл. На посредан начин, Лазар је негативно окарактерисан и посредством савета Милоша Обилића Ивану Косанчићу да ублажи извештај о силини и снази турске војске како не би „забринуо” кнеза и „поплашио” војску:

Немој тако кнезу казивати, jep ће нам се кнеже забринути

и сва ће се војска поплашити.

Једна од централних сцена у драми носи назив преузет из епске традиције: Кнежева вечера у првој, односно Кнежева вечера, која се претвара у велику шаховску партију Вука Бранковића, у другој верзији. Слава, тесно повезана са култом предака, у Симовићевој драми представљена је као причешће („Вечерас је трпеза монашка, а не кнежевска!”), а здравица је насловљена као Молитва кнеза Лазара над косовском трпезом:

Нек немамо ништа, до једно зрно соли!

Ал нек све буде

њиме осољено!

И кад нам све

однесу воде и ватре

то једно зрно

нек нам буде све!

(Симовић 2003: 66)

${ }^{1}$ Ова молитва је преузета и штампа се као самостална песма у Симовићевим збиркама поезије. 
Опозиција слано : неслано у Симовићевом стваралаштву указује, у богатом хришћанском расветљењу, на духовни, смислотворни живот, коме истински умни човек тежи целим својим бићем, с једне стране, и на живот лишен своје суштине и смисла, као његов контрапункт, с друге:

Со је један од најбитнијих момената његове поетике, а опозиција слано неслано једна од најважнијих. У много чему је истоветна опозицији (живети) са смислом - без смисла (Јовановић 2011: 19).

Мотив „последњег времена” у есхатолошком смислу Симовић преузима из списа старе српске књижевности и из косовске епике, где је најизразитије заступљен у песми Зидаґе Раванице (Вук СНП II, 35). И овај, библијски мотив, међутим, писац „спушта” у народ, у пијачне и пиљарске разговоре, највећма између Пиљарице и Рибарице. Страхоте турских мучења, суровост и насиље не плаше и не забрињавају Рибарицу. У иронијском дискурсу, на све приче о смаку света и доласку Агарјана као изразу Божје казне због људских сагрешења, о надолазећем времену у коме ће „живи завидети мртвима”, она има једноставан и јединствен одговор - „А једу ли рибу?” (Симовић 2003: 24):

Као што у песми Зидање Раванице црква од камена опстаје и надживеће и Србе и Турке, тако ће свет Симовићевих рибарица и пиљарица преживети упркос свим страхотама и трагедијама (Катински 2012: 87).

У том контексту јавља се мотив оклеветаног јунака и у епској песми и у драми. Оклеветани јунак, носилац подвига, али и витешке етике, и у епској традицији и у драми јесте Милош Обилић. У првој верзији драме нема изневерених очекивања, Симовић прати традицију у потпуности. Обилић је и у другој верзији приказан као узор светог ратника који даје живот како би скинуо клевету са себе:

\section{ОБИЛИЋ}

Србија није шака зоби, да је позобе

Свака врана коју донесе ветар!

(Симовић 2003: 105)

Мотив причешћа, као један од најизразитијих хагиографских елемената у епској биографији кнеза Лазара, важан је мотивациони агенс и у Симовићевој драми.

Ово је више причешће него вечера!

Ми ћемо сутра бити Христови ратници!

И јешћемо оно што је јео Христос!

(Симовић 2003: 66) 
Свечану узвишеност хагиографских елемената, драмску патетику обликовану у високопарним исказима државних великодостојника, Симовић ублажава поетичким поступцима детронизације, увођењем неочекиваних обрта, гротескних исказа, извртањем ствари на наличје, честим коришћењем ироније и парадокса.

\section{МИЛИЦА}

Не можеш носити тај крст...

\section{СПИРИДОН}

Ја га и не носим... Овај крст носи мене!

(Симовић 2003: 16)

\section{Косовско опредељење}

Од почетка драме поставља се, у различитим ситуацијама и међу различитим саговорницима, кључно питање косовске легенде: шта ми то, у ствари, бранимо на Косову?! Тачније, бранећи Косово, од чега га бранимо, и шта у тој одбрани бива вредно одлуке да се у тој борби положи живот?! У завршном дијалогу кнеза Лазара и Бајазита најизразитије се указује на то да је тај дијалог суштински немогућ будући да се води на две поларизоване и међусобно неукрштајуће равни, метафизичкој и физичкој, духовној и супстанцијалној, видљивој и невидљивој, уз различите и међусобно супротстављене појмовне категорије духа и анти-духа. Тако се овај разговор пресликава и на однос кнеза Лазара према Милици, али и на однос Вука и његовог брата Герасима, као и на однос Милице и издајничке властеле. И ту лежи један од проблема ове драме, будући да се тачка гледишта мења, али гледишта остају неизмењена.

Ипак, у овој драми, као и у Симовићевом делу у целини, иако је наизглед „све дефинисано, разне могућности остале су отворене, песник је себи оставио могућност нових опредељења" (Павловић 1987).

Цела битка се одиграва на прелазу, боље речено, на успону од земаљског до небеског царства. Опредељење за царство небеско је мотив који се првенствено везује за средњовековну књижевност, а одатле је пренет и у нашу епику. Носилац и бранилац ове идеје у епским песмама о Косовском боју је кнез Лазар, који је представљен и као ратник и као светац. У његовом лику су сједињена „два основна мисаона тока епске поезије о Косову: идеолошка неприкосновеност српског средњег века и ратничка национална част” (Пешић, Милошевић-Ђорђевић 1996: 134). 
Избор кнеза Лазара само је фиктивни избор. У суштини, кнез мора да бира оно што бира, као што и Вук Бранковић мора да бира оно што му је додељено у традицији:

\section{ЛАЗАР}

Страдаћемо, овако или онако!

Ал можемо да бирамо: да нестанемо пузећи, као турске слуге и потурице,

Или да изгинемо како приличи људима!

(Симовић 2003: 15)

Кнез размишља у метафизичким релацијама, а ставове исказује у бритким сентенцама, често заснованим на паралелизмима по супротности:

\section{ЛАЗАР}

Боље је да нас унуци мртве памте, него да нас синови живе забораве!

(Симовић 2003: 15)

Слово о кнезу Лазару патријарха Данила доноси идентичну стилизацију кнежевог говора. „Боље је нама у подвигу смрт, него ли са стидом живот. Боље је нама у боју смрт од мача примити, него ли плећа непријатељима нашим дати” (Михаљчић 2001: 148).

У чувеном тексту Шта је то косовско опредељење Зоран Мишић износи луцидну идеју да је реч о духовном процесу који се понавља у времену, „као закон историјске нужности”, од Даниловог Слова о кнезу Лазару до 20. века:

Косовско опредељење је опредељење свих оних који су радије бирали „у подвигу смрт, него ли са стидом живот”. Када данас читамо Похвалу кнезу Лазару од патријарха Данила III, написану 1392. или 1393. године, чини нам се као да слушамо покличе који су се 27 . марта разлегали на београдским улицама: „Боље је нама у подвигу смрт, неголи са стидом живот. Боље је нама у боју смрт од мача примити, неголи плећа непријатељима нашим дати.” И питамо се: није ли то увек било једно исто опредељење које нас је нагонило да се боримо за „изгубљену ствар”, да се подижемо на устанак у тренуцима када је цео свет веровао да нам нема спаса? Нисмо ли управо у таквим тренуцима, када је претило да нестанемо, долазили до најпуније потврде свога постојања? За оне који време броје рачуницом невремена, а победе рачунају бројем непријатељских офанзива, косовско опредељење није само мит већ и закон историјске нужности. (Мишић 1963/II: 174)

У косовској епици, избор између земаљског и небеског царства опеван је у песми Пропаст ц̧арства српског, где се лик кнеза Лазара уклапа у тип 
светог владара-мученика (Сувајџић 2005: 259). Страдалници за веру се овенчавају мученичким венцем, и кроз делатни подвиг улазе у „небеско царство”, у вечни живот, јеванђеоску есенцију духа.

Страх, студена језа и дрхтање, које кнегиња Милица осећа пре битке у првој верзији, пресликавају се у идентично стање стрепње и неизвесности у турском табору, и имају пандан у дрхтавици и студеној јези која овладава султаном Муратом као наговештај скоре смрти:

\section{МИЛИЦА}

Да ли је ово изненада захладило, или се страх прво осећа као зима и језа?

(Симовић 1989: 26)

\section{MУPAT}

Не хвата мене језа од њине литургије!

Језа ме хвата од ове летње зиме!...

Осећаш ли да јутрос месечина

мирише на липов и багремов мед?

(Симовић 1989: 159)

Ова кружна идентификација самртне језе и апокалиптичке атмосфере у другој верзији је изгубљена. Само сагледавање догађаја из две међусобно супротстављене тачке, српске и турске, упућује на идејно решење слепог певача Филипа Вишњића у песми Почетак буне против дахија. Милосрдни, човекољубиви пропламсаји у карактеризацији лика султана Мурата, оштро опонирани Бајазитовим речима и поступцима, упућују на познати мотив „последње воље султана Мурата”, да турска влада буде блага и праведна, како не би довела до побуне и краха Царства.

\section{Митопоетска перспектива}

У Симовићевој драми Косово је свуда, у вертикалној и хоризонталној перспективи. На небу, на земљи, испод земље. Косово је пут и раскрсница путева. Где год да се човек налази, налази се на Косову. Шта год да предузима, предузима због Косова. Када човек помисли да је близу, он се удаљава од Косова (удаљавајући се симболички од себе и своје суштине). Када се удаљава, приближава му се. Када помисли да је стигао, схвата да се до Косова не може стићи. Када помисли да је поље саткано од светлости, изнад њега се склопи мрак. У другој верзији: 
МИЛИЦА

(пришавщи прозору који гледа на југ):

Види ли се Косово одавде?

ЛАЗАР

Не види се. Али се зна где је.

МИЛИЦА

Где?

ЛАЗАР

Видиш ли оно велико сијање у небу?

МИЛИЦА

Видим.

\section{ЛАЗАР}

Косово је тачно испод тог сијања!

\section{МИЛИЦА}

Онај мрак?

(Симовић 2003: 18)

И у првој:

\section{МИЛИЦА}

Ја сам те питала о Косову...

\section{ЛАЗАР}

Па ја све време о Косову и говорим!

Пењући се, или силазећи, не знам, сада смо стигли на Косово!

А Косово је раскрсница и вага! 


\section{МИЛИЦА}

Каква раскрсница? Каква вага?

\section{ЛАЗАР}

На Косову треба да одлучимо

хоћемо ли горе, у Бога и светлост, или доле, у гмизавце и мрак!

Косово је вага на којој се мери

хоће ли нас бити, или неће!

(Симовић 1989: 25)

Косово је митско разбојиште, симболичка вертикала која је смештена на тромеђи космичког дрвета света, према просторној и симболичкој дихотомији горе : доле. Вечита, и често неприметна, борба горњих светова, у којима влада „свилена светлост”, са демонима подземља, који вребају на човекову душу из „сукнених мракова” пакла, одлика је целокупног Симовићевог дела. Косово тако постаје раскрсница, вага, кључ, nут, „страшна међа" између две непомирљиве стварности:

Дуализам горњег - светог, чистог, светлог - и доњег - проклетог, нечистог, тамног - обележава цело дело Љубомира Симовића. Трипартитно дрво света, сагледано у својој исконској, митској целовитости - оцртава се као једна од основних естетских и значењских вертикала његовог стваралаштва. (Пешикан Љуштановић 2010: 396)

Док у Хасанагиници јунаке поларизује у времену, тако што их смешта у прошлост или будућност, у Боју на Косову ликови су јасно диференцирани просторном перспективом. Дихотомија двор : пијаща означава два круга историје и јасно поларизоване носиоце њених основних токова. Први су они који су смештени у званичан, видљив ток, и који ће остати упамћени у народним песмама и побележени у историјским изворима, хроникама, летописима, о којима ће се испредати приче и легенде: владари, јунаци, издајници, представници владарских дворова, свештеничких митри и великашких одора. Други пол драмске радње одвија се у сенци тих дворова, на пијаци у Новом Брду, „крај градске капије, познате као Врата шустера". Јунаци и јунакиње овог круга су корифеји обичног, носиоци незваничне, апокрифне историје, која неће бити упамћена ни у једном званичном спомену на Косовски бој, али ће својом бесмртном виталношћу, надживети и бој, и време, и изворе који о њему говоре. Они су носиоци профаног, пролазног, колоквијалног, које се специфичним драматуршким поступком претвара у узвишено, свето, непролазно. Ово, његошевско „коло”, глас народа, антички хор, осољена мисао обичног живота који је 
вечан и непролазан, у другој верзији драме добија много више на значају. Сачињавају га Рибарица, Велислава, Пиљарица, Војиша...

Материјалну, вештаствену стварност, „царство земаљско”, са обе стране, и готово једнаким аргументима, заступају Вук Бранковић и султан Бајазит. Ево како изгледа Вукова „визија”:

\section{ВУК БРАНКОВИЋ}

Ова соба је велика седам са осам!

Онај бор је висок тридесет метара!

Онај во, пред ковачницом, тежак је седамсто кила!

Оно буре захвата двеста литара!

Над нама је таван за четрес кола сена!

Звоно на торњу у четири избија четири,

У седам сати избија седам пута!

Ето шта је моја визија!

Подрум је камени, буре је дрвено, рукавице су вунене!

Змија је отровна, бресква је слатка, пелен је горак!

Срба је мало, Турака је много!

Један и један су два,

И то је цела прича и филозофија!

Зашто ме гледаш?

(Симовић 2003: 39)

У завршници драме Вуку терцирају Левчанин и Тамнавац, као препознатљив глас локалних моћника, вазда поводљивих и спремних да следе оног ,лидера” који им да најуноснију понуду, једнако у 14. веку као и данас. И само завршно поглавље: „Две Србије, Лазарева и Вукова”, указује на суштинску дихотомију између два схватања живота, части, дужности, патриотизма, достојанства.

У самој драми активна је улога патријарха Спиридона, који у потпуности подржава Лазарева државничка предузећа:

\section{ЛАЗАР}

Ја скупљам војску, Спиридоне, а ти скупљај све митрополите и владике, све синђеле и протосинђеле, архијереје, архимандрите, монахе, јеромонахе, свештенике, ђаконе и ђаке, и испоснике, из свих цркава, скитова, испосница, широм Србије, да нам војску причесте уочи битке!

(Симовић 2003: 15) 
Да је бој на Косову изузетна битка, бој између светова, цивилизација, видљивог и невидљивог, духа и тела, вере и невере, свих аспеката људског бивства на свету, сведоче не само државници и ратници, дворјани и дворкиње, духовници и монаси, већ и обичан свет, до кога је писцу драме толико стало. То је она коренита „премјена” о којој сведочи Вук Караџић, у историји српске културе и свим аспектима живота:

\section{РИБАРИЦА}

Мора да им је много пригустило, човече, кад зову и тебе, у твојим годинама!

\section{ВОЈИША}

Пригустило је, као што није никад!

\section{ВЕЛИСЛАВА}

Било је и раније и бојева, и ратова, али ово се не памти!

\section{ПИЉАРИЦА}

Раде, кажу, све туцалице, све ковачнице, кажу, и топионице! Јуче се, кажу, поломило гвоздено, а јутрос, кажу, и сребрно коло!

(Симовић 2003: 20)

Косово се декларативно одређује знатно шире од једног историјског догађаја, или географског појма. Косово постаје синоним за време и непролазни живот у времену, огледно и удесно место српске историје:

\section{ПИЉАРИЦА}

На Косову нам се, кажу, решава судбина!

\section{РИБАРИЦА}

Имам ја Косово и без Косова!

Косово је мени где год се окренем!

Косово је мени сваки дан!

Да ми је знати

што се тресу толико пред тим Турцима!

Ако долазе Турци, не долазе скакавци!

(Симовић 2003: 23) 
Косово се намеће као „отиписано бојно поље”, као мизансцен на коме се одвијају све усудне битке српскога народа, пре свега оне које се воде у духу. У првој верзији то је снажније наглашено:

\section{МИЛИЦА}

Кажи ми, Лазаре...

Ко је за бојиште изабрао Косово?

Ти, или Мурат?

\section{ЛАЗАР}

Ни ја, ни Мурат...

Косово се изабрало само!

(Симовић 1989: 26)

Централни простор, значењска и вредносна оса обе Симовићеве верзије драме Бој на Косову јесте простор Косова, обликован у широком распону од конкретне просторне сценске индикације до централног историјског, етичког, духовног симбола. Тако се рецимо, у обе верзије драме питање о путу који води на Косово помера од свог основног, буквалног значења (Богоје долази из правца Расине и не може да се оријентише у простору, зато што је навикао да иде из Призрена) ка симболичном дубљем смислу који се открива у одговору. И монах Теофан (у првој) и Праља (у другој верзији) одговарају готово идентично: „Данас у Србији и нема другога пута, / до пута на Косово" (Пешикан Љуштановић 2010: 397).

У првој верзији драме путеви воде и на Косово, и са Косова. У другој пак путеви воде само на Косово. Пут са Косова резервисан је само за издајнике:

\section{БОГОЈЕ:}

Еј! Црноришче!

Да л се на ову страну иде према Косову?

\section{ТЕОФАН}

Јесте, на ту!

Али се иде и на ону тамо!

И на ону онамо!

И на ону страну с које си дошао!

Што се чудиш?

Сваки ће те правац тамо одвести!

Данас у Србији нема другога пута 
до пута на Косово, или са Косова!

(Симовић 1989: 11-12)

\section{БОГОЈЕ:}

Ниси ми казала иде ли овај пут...

\section{ПРАљА:}

На Косово? Иде!

А иде и онај тамо!

И онај онамо!

Можеш и у овом и у оном правцу!

И оним узбрдо, и оним низбрдо!

И оним уз ветар, и низ ветар!

И да оћеш не можеш промашити:

данас у Србији и нема другога пута, до пута на Косово!

Ни других путника, до путника на Косово!

Ја сам на Косово испратила оца, сина, два мужа и четири брата!

Питам се само колко ће вас бити кад се будете враћали с Косова!

(Симовић 2003: 10)

\section{Слободан човек или конвертит}

Прича о видару Богоју, који је „medicus et cyrorgico et barberius de Preserin", послужила је писцу за две ствари. Најпре, у драматуршком смислу, Богоје је био идеалан повод за драмску интригу и клеветање Вука Бранковића, који ће оптужити Милоша Обилића управо користећи епизоду са видаром на почетку дела. На крају, лик хећима Мустафе покренуће питање конвертитства, издаје, али и сложености људске природе. Могу ли, наиме, видање људи, лечење и хуманитарни рад бити национално омеђени и ограничени верским и етничким дистинкцијама? Може ли прогоњени човек бити слободан да изабере своју слободу? Може ли, и под којим условима, ропство постати слобода?

Парамунац, а посебице Вук Бранковић, оптужују лекара, хирурга и берберина из Призрена за ширење лажних вести, ухођење српске војске и сејање панике пред одлучујући бој, како би се то кривично дело у речнику 
многих ауторитарних влада и друштава данас оквалификовало. Посебно су жбирима и припадницима репресивног система сумњиви реквизити које он носи у својој торби - књиге и медикаменти. Човек који носи књиге и медикаменте у торби, у сваком времену, сваком поретку, пред сваким режимом и сваком влашћу мора бити једнако сумњив.

Врло је вешто драматуршки уклопљена прича о познанству Милоша Обилића и Призренца Богоја из претходног боја (бој на Плочнику), којом ће се мотивисати њихово пријатељство, а што ће послужити Вуку Бранковићу за лажну оптужбу о издајничкој завери на кнежевој вечери:

\section{ПАРАМУНАЦ}

И шта ти, кад ниси војник, тражиш на Косову?

\section{БОГОЈЕ}

Знаш ли ти колико ће за мене бити посла на Косову? Знаш ли ти колико ће на Косову бити прободених џигерица, плућа, стомака, просутих црева и мозгова, одсечених ногу и руку, проваљених ребара и лобања, згажених и згњечених прстију, ископаних очију, сломљених кичми, сломљених бутњача, цеваница и карлица, и прострељених вилица и вратова? Биће крви да по њој возимо чамце!

(Симовић 2003: 26)

И њихов последњи сусрет је драмски врло ефектно уприличен. Хећим Мустафа, алиас видар Богоје, наставља да испуњава Хипократову заклетву под другим именом и у измењеним околностима. У идејној сфери драме, то оставља простор за још једно важно метафизичко питање, које у драматуршком смислу отвара нови психолошки конфликт: може ли конвертит бити позитивни јунак драме? Није ли он својим конвертитством, макар и у име живота, поништио живот сам?! Хоће ли његов нови живот моћи да оправда стари? Вреди ли било каквог оправдања чин преласка на страну непријатеља? Писац, наравно, не заузима став. Али евидентно је да у Богојевом речнику од почетка до краја драме нема места за појмове отаџбине и нације, вере и невере, пријатеља и непријатеља, рођака и сународника, окупатора и колонизатора. У његовом језику постоје само речи које означавају живе и мртве, болесне и рањене. Које треба лечити, или сахранити, ма које вере, нације, језика и других идентитетских обележја они били: 


\section{МУСТАФА}

Нисам ја више Богоје, Обилићу!

И више нисам ни медикус, ни хришћанин!

Него Мустафа, хећим и муслиман!

Више не идем у цркву, него у џамију!

\section{ОБИЛИЋ}

За ме Бога, Богоје...

(Симовић 2003: 108)

\section{ОБИЛИЋ}

Брзо си научио ту лекцију... Мустафа! Земљу променио, име и веру променио! На крају, од тебе није остало ништа!

\section{МУСТАФА}

Остало је!

\section{ОБИЛИЋ}

Шта ти је остало?

\section{МУСТАФА}

Остале су ми ове сакулице!

Остала су ми, ево, ова стенила!

Остало је ово грнце, овај налевак!

Овај мелем! Ова игла! Овај конац!

Ја истом иглом и концем ушивам ране!

Истим мелемом лечим сломљену кост!

(Симовић 2003: 110)

Прогањањем без кривице, не Турци, већ Бранковић и његови људи су га насиљем отерали у другу веру и Богоје је постао Мустафа. Уместо дрвених кашика изабрао је другу веру и пилав. Али, ипак, он се разликује од Србина Хамзе, који своју оданост доказује на српским главама [...] над својима и као кукавица удара везане јунаке: 


\section{ОБИЛИЋ:}

Ко је онај што ме је тукао везаног?

\section{МУСТАФА:}

Србин Хамза!

\section{ОБИЛИЋ:}

Зато он, значи удара и кад не треба!

\section{МУСТАФА:}

Потурици нико не верује!

Ако је Турчин крвав до лаката, потурица мора да буде до рамена!

(Симовић 2003: 109)

\section{Дијалошки епилог драме}

У биографском делу Константина Михаиловића из Островице, које се обично назива Јаничареве успомене или Турска хроника, а настало је крајем 15. века (између 1496. и 1501), на пољском језику, сачуван је разговор између Бајазита и кнеза Лазара пред кнежево погубљење:

И онда је рекао Бајазит кнезу Лазару: „Ето видиш како леже на носилима отац мој и брат мој. Како си се смео одважити да се њему успротивиш?” Кнез Лазар је ћутао. Рече војвода Крајмир: „Мили кнеже, одговарај цару, јер глава није као [врбов пањ] да по други пут израсте.”

Тада кнез Лазар рече цару: „Веће је чудо како се отац твој смео одважити да нападне српску краљевину. А кажем ти, царе Бајазите: да сам то раније знао што сада очима видим, морао би и ти на трећим носилима лежати. Али је сам Господ Бог тако изволео учинити због грехова наших. Нека буде воља божја." (Живановић 2006: 179)

Овај извор је скоро пресликан у сцени у којој се одвија завршни дијалог између кнеза Лазара и Бајазита. У ствари, чини се да је управо Константин Михаиловић инспирисао аутора за решење да завршни дијалог не припадне Лазару и Мурату, као вођама зараћених страна и жртвама страшног боја, што би било природно драматуршко решење, већ да се тај дијалог води између кнеза Лазара и Бајазита, као представника две различите генерације и животне филозофије. Њему, пак, претходи, разговор између заточеног Милоша Обилића и султана Мурата, пре Милошева 
погубљења. Оба су дијалога обликована на принципу контраста. Први се води између ратника који крвљу спира своју част и брани своју реч и умирућег владара, који не разуме тај безумни, самоубилачки чин, но га свеједно поштује, и труди се да у аманет то поштовање пренесе и сину, бруталном и крвожедном властодршцу и тиранину, који нема времена за било какву другу мисао осим преузимања власти и уклањања свих препрека на путу до ње. Други припада кнезу који се борио у метафизичкој бици за спас душе, као опонент окрутном младом политичару ратнику који заступа нову, материјалистичку филозофију живота, прагматичну и макијавелистичку, која много више одговара модерном, обезљуђеном времену капиталистичке транзиције и савременом човеку 20. века, о коме Симовићева драма говори барем онолико колико и о историјским догађајима и јунацима из 14. века.

\section{ИЗВОРИ}

Симовић, Љубомир. Бој на Косову. Београд: Српска књижевна задруга, 1989.

Симовић, Љубомир. Бој на Косову. Друга верзија. Београд: Стубови културе, 2003.

Симовић, Љубомир. Ковачница на Чаковини. Одабрана дела Љубомира Симовића. Београд: Београдска књига, 2008.

\section{ЛИТЕРАТУРА}

Бандић, Душан. Царство земаљско и иарство небеско. Београд: Библиотека XX век, 2008.

Врбавац, Јасмина. Жртвовање краља. Нови Сад: Позоришни музеј Војводине, 2005.

Громовић, Милан. „Структура митске слике у историјским драмама Бој на Косову и Бој на Косову, Друга верзија Љубомира Симовића". Philologia Mediana XII/12 (2020): 573-585.

Ђурић, Војислав. Косовски бој у српској књижевности. Београд: СКЗ, Нови Сад: Матица српска, Приштина: Јединство, 1990.

Живановић, Ђорђе. Живот и дело Константина Михаиловића из Островице. Петар Буњак (прир.). Београд: САНУ, 2006.

Јевтић, Милош. Рукопис времена: разговори са Љубомиром Симовићем. Београд: Београдска књига, 2005.

Јиречек, Константин, Јован Радонић. Историја Срба I-II. Београд: Просвета, 1988. 
Јовановић, Александар. „Песничке вертикале Љубомира Симовића”. Песничке вертикале Љубомира Симовића. Зборник радова. Александар Јовановић, Светлана Шеатовић Димитријевић (ур.). Београд: Институт за књижевност и уметност - Учитељски факутет, Требиње: Дучићеве вечери поезије, 2011. 17-33.

Катински, Јасмина. „Бој на Косову Љубомира Симовића и народна традиција". Годишњак Катедре за српску књижевност са јужнословенским књижевностима VII (2012): 83-99.

Љубинковић, Ненад. „Најстарији записи прозних народних предања о косовскоме боју на простору Косова". Зборник у част Војислава Ђуpuћa. Иво Тартаља (ур.). Београд: Филолошки факултет - Институт за књижевност и уметност, 1992.

Љубинковић, Ненад. Косово у памћењу и стваралаштву. Београд: Народна библиотека „Вук Караџић”, 1989.

Милошевић-Ђорђевић, Нада. Косовска епика. Београд: Завод за уџбенике и наставна средства, 1990.

Михаљчић, Раде. Лазар Хребељановић, историја, култ, предање. Београд: Српска школска књига - Knowledge, 2001.

Мишић, Зоран. „Шта је то косовско опредељење”. Реч и време II. Песничко искуство. Београд: Нолит, 1963. 169-179.

Павловић, Миодраг. „Једно читање поезије Љубомира Симовића”. У: Симовић, Љубомир. Хлеб и со. Београд: СКЗ, 1987.

Петровић, Предраг. „Симовићева песничка реторика”. Песничке вертикале Љубомира Симовића. Зборник радова. Александар Јовановић, Светлана Шеатовић Димитријевић (ур.). Београд: Институт за књижевност и уметност - Учитељски факутет, Требиње: Дучићеве вечери поезије, 2011. 123-143.

Пешикан Љуштановић, Љиљана. „Простор Косова у Боју на Косову Љубомира Симовића". Косово и Метохија у цивилизацијским токовима. Књ. 2. Валентина Питулић (ур.). Косовска Митровица: Филозофски факултет Универзитета у Приштини, 2010. 395-408.

Пешић, Радмила, Нада Милошевић-Ђорђевић. Народна књижевност. Београд: Требник, 1996.

Пијановић, Петар. „Питања експлицитне поетике Љубомира Симовића”. Песничке вертикале Љубомира Симовића. Зборник радова. Александар Јовановић, Светлана Шеатовић Димитријевић (ур.). Београд: Институт за књижевност и уметност - Учитељски факутет, Требиње: Дучићеве вечери поезије, 2011. 33-59.

Ређеп, Јелка. Косовска легенда. Нови Сад: Прометеј, 2007.

Самарџија, Снежана. Биографије епских јунака. Београд: Друштво за српски језик и књижевност Србије, 2008. 
Сонди, Петер. Студије о драми. Нови Сад: Orpheus, 2008.

Станисављевић, Миодраг. Епика и драма. Београд: Republica Informatica, 2006.

Сувајџић, Бошко. Јунащуи и маске. Београд: Друштво за српски језик и књижевност Србије, 2005.

Фрајнд, Марта. Историја у драми и драма у историји. Огледи о српској историјској драми. Нови Сад: Прометеј - Стеријино позорје, Београд: Институт за књижевност и уметност, 1996. 173-190.

Хамовић, Драган. „Косовско опредељење у поезији Љубомира Симовића”. Песничке вертикале Љубомира Симовића. Зборник радова. Александар Јовановић, Светлана Шеатовић Димитријевић (ур.). Београд: Институт за књижевност и уметност - Учитељски факутет, Требиње: Дучићеве вечери поезије, 2011. 303-319.

Grušanović, Zlatko. Tri drame Ljubomira Simovića. Beograd: Zadužbina Andrejević, 2010.

Orbin, Mavro. Kraljevstvo Slovena. Београд: SKZ, 1968 [Венеција, 1601]. 